\title{
Development of Instruments for Creative Thinking Skills Tests on Momentum and Impulse for High School Students
}

\author{
Mawarni Saputri \\ PostGraduate, Universitas Negeri Medan \\ Medan, Indonesia \\ e-mail:mawarni.saputri48@gmail.com \\ Eva Marlina Ginting \\ PostGraduate, Universitas Negeri Medan \\ Medan, Indonesia \\ e-mail:evamarlina@gmail.com
}

\author{
Togi Tampubolon \\ PostGraduate, Universitas Negeri Medan \\ Medan, Indonesia \\ e-mail: togitampubolon011@gmai.com
}

\author{
Rajo Hasim Lubis \\ Universitas Negeri Medan \\ Medan,Indonesia \\ e-mail:rajohasimlbs@unimed.co.id
}

\begin{abstract}
The purpose of this study is to find out the steps for developing instruments and characteristics of creative thinking skills test on momentum material and impulses. The research subjects were students of class X IPA 1 Cut Nyak Superior High School Dhien Langsa who had received momentum and impulse material. The type of research used is research and development $(\mathrm{R} \& D)$. The research conducted refers to the development of a product in the form of a creative thinking skills test instrument. Before the test instrument for creative thinking skills was tested on students, expert validation tests were carried out first. The subject of product development consists of content or material experts, instrument experts, and linguists. The data analysis technique used in this study is descriptive analysis techniques. The conclusions obtained after the research are the process of developing creative thinking skills test instruments for physics lessons at Cut Nyak Dhien Langsa High School through several stages, namely the analysis of requirements and characteristics, stages of designing or designing grids and questions, product validation stage, and trial stage product; The characteristics of the test instruments for creative thinking skills developed were declared valid with high interpretations, reliable with very high interpretations, and the level of difficulty and differentiation were classified as good; The creative thinking skills of Cut Nyak Dhien Langsa High School students in class $\mathrm{X}$ are classified as good (creative).
\end{abstract}

\section{Keywords-Development, Creative Thinking Skills Test}

\section{INTRODUCTION}

Based on the results of research by the 2015 GCI (Global Creativity Index), Indonesia ranks 115th out of 139 participating countries with a global creativity index of 0.202 . In ASEAN, Indonesia is ranked 6th out of 6 countries that are the object of analysis. This shows that the creativity of the Indonesian people is still low. Meanwhile, in facing the challenges of the future, in addition to relying on awareness and literacy towards technology, creative thinking skills are also very much needed [1].

Based on data obtained from the 2017 National Education Standards Agency (BSNP) about the results of the national examinations for each province throughout Indonesia, particularly the results of the National Examination in the province of Aceh at the high school level majoring in Science are very sad compared to the National average. The average grade of Aceh National High School National Examination is 42.18, while National with a value of 53.47 and ranks 33 out of 34 other provinces in Indonesia. The female students in Aceh were only able to know $30 \%$ of the reading material and it turned out they were very difficult to answer the questions in the form of descriptions that needed high-level thinking. The problem of the students' low analytical skills also in learning students are very accustomed to memorizing, working on multiple-choice type questions and not being trained to work on creative thinking problems [2].

According to Guilford, creative thinking as the ability to see the various possible solutions to a problem is a form of thought which until now still lacks attention informal education [3]. In general, the results of a national survey of education in Indonesia show that the formal education system in Indonesia still lacks opportunities for the development of creativity [4].

At the beginning of the 21 st century, creativity is needed and continues to increase in every field of human activity [5]. Even now, creativity is considered "... an essential life skill, which needs to be promoted by the education system" [6] because it has the potential to solve various social, political and economic problems. Creative thinking skills help students create new ideas based on the knowledge they have to solve problems from different perspectives. Learning by developing creative thinking skills can make learning more meaningful and enjoyable. Creative thinking skills are also needed to find new innovations in human life.

Creative thinking skills are very important for someone to be able to foster a smooth and flexible idea, can review problems from various perspectives, and be able to bring up original and unique ideas [7]. In education, to find out the creative thinking skills possessed by students need to carry 
out an evaluation. Evaluation in education one of which can use a test that serves to provide information about certain aspects [8]. In addition to getting information about one's creative thinking skills, the use of tests can also improve creative thinking skills. But in general, the tests used in schools only include tasks that must find one correct answer, so that students' creative thinking skills cannot be measured significantly [9].

The situation that occurs in the world of education today is that many teachers have not made and used written tests that are truly appropriate in measuring the indicators of learning achievement and cognitive domains of students. The results of the study conducted by Samosir, Baehaki, Agustin stated that many found evaluation activities in various schools that were not in accordance with the rules of good test preparation [10], [11],[12].

The above statement is also supported by the facts of the preliminary study through observation and interviews with researchers with physics teachers in one of the Langsa City High Schools which shows that the teachers at the school are still having difficulty making tests that trace high-level thinking skills, especially creative thinking skills. This proves that in making the test, the teachers have not understood the principles. In addition, these teachers have never made a test instrument to measure students' creative thinking skills even though the school where they teach uses the 2013 curriculum that requires students to bring up their creativity in the learning process, so it can be concluded that so far the tests made by teachers have not been directed well for measuring students' thinking skills.

Forms of tests that can be used to train students' creative thinking, one of which is to use essay forms. Tests with these forms can be used to measure the level of students' creative thinking skills with divergent thinking processes.

According to Munandar in Sari, et al, the process of divergent thinking is the process of thinking in various directions and producing many alternative solutions [1]. The form of the essay test is one type of test that requires students to think divergently by giving freedom to participants to issue answers according to the results of their thoughts and the answers are expressed in their own sentences. This form of essay test can produce, compile, state and develop an idea with a variety of perspectives held by students.

\section{RESEARCH METHOD}

The study was conducted at Cut Nyak Dhien Superior High School, having its address at Jalan Perumnas, Langsa Baro Subdistrict, Langsa City. This research will be conducted in semester II T.A 2018/2019.The subjects in this study were test instruments for creative thinking skills. The test will be carried out to class X IPA 1 students in Cut Nyak High School Dhien Langsa who have received material momentum and impulses. The type of research used is research and development. The research conducted was directed at the development of a product in the form of a creative thinking skills test instrument. Before the test instrument for creative thinking skills was tested on students, expert validation tests were carried out first. The subject of product development consists of content or material experts, instrument experts, and linguists.

Conceptually, the research and development approach includes 10 general steps, as described by Borg \& Gall, as shown below:

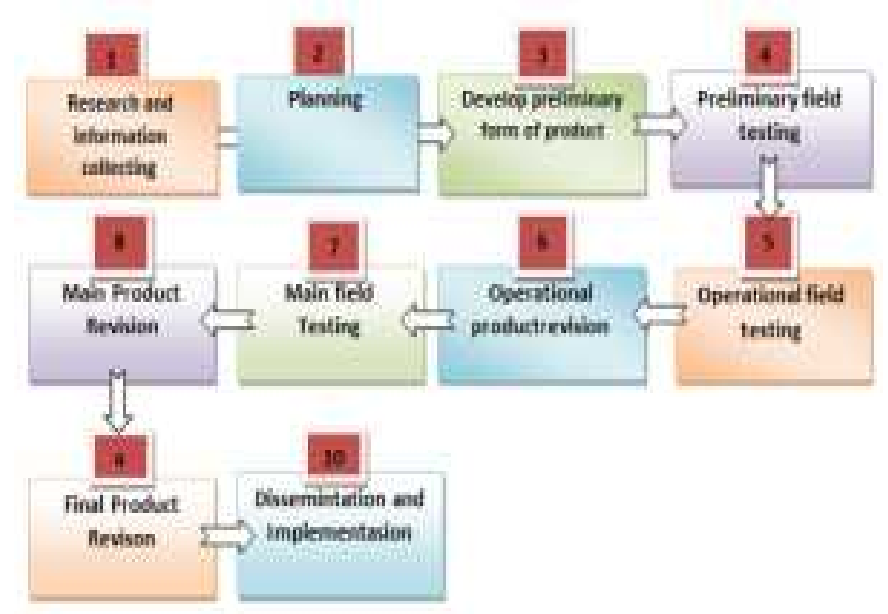

Fig. 1. The procedure scheme for developing adaptation results from the procedure for developing Borg \& Gall

The research instrument used in this study was a creative thinking ability test instrument in the form of a description that fulfilled all test indicators, namely: (1) fluency, (2) flexibility, (3) elaboration, (4) originality; The validation sheet of the test instrument is directed at content validation, construct validity, language suitability used, time allocation given and instructions on the question; Questionnaires are used to collect information about students 'responses to the students' high-level ability test instruments and are distributed to students after testing or working on the test instruments. The data analysis technique used in this study is descriptive analysis techniques.

\section{RESULT AND DISCUSSION}

The development of an instrument for testing creative thinking skills has been developed by following the modification steps of Borg \& Gall. This instrument has been developed starting from the needs and characteristics analysis stage, designing or designing grids and questions, product validation, product testing and revision to produce a product. The product in question is a test instrument for creative thinking skills physics.

The instrument for testing creative thinking skills in material momentum and impulses in this development research has undergone three revisions. The first revision received several inputs, including from the supervisor, then received expert lecturer validation, as well as the physics teacher validation at the development stage. The second revision received input or suggestions for improvement from the results of individual trials through the results of the questionnaire responses of students.

The third revision is to make improvements to items that are not valid when tested in a large group test. There is one item that is aborted or omitted because it does not comply with the specified quality criteria. These invalid questions can be caused by several things, namely the questions that are made less clear so that the students are confused to answer them. The other reasons for the question are invalid because the answers given by students are inconsistent. This 
inconsistency can be because students are lazy to answer questions given or simply students answer the question carelessly. Whereas in the fourth revision the absence of suggestions or improvements from the test instruments of creative thinking skills developed.

Before the development process is carried out, a quality criterion for the test instrument has been established to see the extent of the success of the product produced. Based on the results obtained at the validation stage, namely expert judgment and large group trials, the test instruments produced reach the criteria that have been set, namely valid and reliable. This means that the instrument that has been developed can be applied properly. These results are in line with the research of Alrubaie [13] stating from the results of his research that tests of creative thinking that have validity and reliability are appropriate then the test can be applied successfully.

The characteristics of the test instruments for creative thinking skills developed from this study were declared valid with high interpretations, reliable with very high interpretations, moderate difficulty, and good differentiation. The level of difficulty of test instruments and distinguishing tests of test instruments that are developed as a whole has been classified as good, according to established quality criteria so as to produce the final product test instruments that are good and according to the criteria of the test instruments. Thus, the final product test questions have produced this study consisted of 15 items of description with an allocation of $2 \times 45$ minutes.

Based on the results of a large group trial, in addition to obtaining the characteristics of the test instruments developed also the results of students' creative thinking skills were also obtained. This analysis aims to determine the value of students' creative thinking skills in the categories of very good, good, sufficient and lacking and very lacking.

The students' creative thinking skills based on the results of the analysis obtained the average creative thinking skills of students in the small group test of 57.79 with sufficient categories, while the average value of creative thinking skills of students in the large group test was 68.27 with good categories (creative).

The average results obtained by students are good, but still, further efforts are needed by the teacher to be able to give more questions that can spur students' creative thinking skills to be very good (very creative). Instruments of creative thinking skills that have been developed valid and reliable and meet good test criteria will be able to measure students' creative thinking skills. These results are also reinforced by the study of Kohl [14] which shows that to measure the creativity of students physics is used standard instruments and is useful for developing special instruments of physics, besides that it can also increase creativity through direct instruction.

Hong and Milgram [15] state that measuring creativity in students can be seen from scores of fluent thinking skills (number of ideas or answers), elaborate thinking skills (many details on answers or ideas), flexible thinking skills (many different categories or ideas ), and original thinking skills (the number of unique ideas assessed by experts or by statistical tabulations).

From the results of the study, it was found that the percentage of indicator achievement was fluent, the highest value was obtained compared to other indicators. This means that in general students are able to spark lots of ideas, answers, problem solving, provide many ways or suggestions for doing many things and always think of more than one answer.

In the percentage of achievement indicators flexible, obtained the lowest value compared to other indicators. This shows that students have not been able to optimally provide various interpretations of a picture, story or problem and use various strategies and ways to solve problems. This result is in line with Setyawan'sresearch, showing that students' flexible thinking skills are low because students have not been able to provide various alternative answers to a question that requires diverse answers [16].

In the percentage of achievement of indicators of originality and elaboration, the average student has begun to use his own way of solving problems and can provide a detailed explanation of problem solving. This can be seen from the category that is classified as good on both indicators of creative thinking.

The use of test instruments as assessment for learning is needed to develop students' thinking skills. This is in line with the research conducted by Klenowski [17]. The results obtained indicate that the assessment for learning, the process of identifying the development of learning, is able to develop students' thinking abilities. Thus, the use of test instruments for creative thinking skills as an assessment for learning is able to develop students' thinking abilities.

In order to obtain optimal results, various efforts have been made in conducting research on developing creative thinking skills test instruments and testing the quality of these products. Researchers have as much as possible to avoid factors that can make research results not optimal. However, there are still several factors that are difficult to control. First, this research only carried out the process of developing test instruments for creative thinking skills in high school physics subjects with material momentum and impulses.

Secondly, this study involved a limited number of research subjects, namely intrusive testing only carried out on 20 students during the small group test and 40 students during the large group test so that the bias factor still influenced the results of the study. Third, students are not accustomed to working on the questions on the test instruments of creative thinking skills because students tend to be devoted to the ability to solve questions with procedural formulas. 


\section{IV.CONCLUSION}

Based on the results of research, development, and discussion that has been stated previously, it can be concluded that the process of developing creative thinking skills test instruments for physics in High School Cut Nyak Dhien Langsa is superior through several stages, namely the analysis of needs and characteristics, stages of designing or designing grids and question, product validation stage, and product testing phase; The characteristics of the creative thinking skills test instruments developed were declared valid with high interpretations, reliable with very high interpretations, and the level of difficulty and differentiation were classified as good categories. Of the four criteria, the test instrument for creative thinking skills developed has good quality instruments; The creative thinking skills of Cut Nyak Dhien Langsa Superior High School students in class $\mathrm{X}$ belong to the category of good (creative) with an average value of 68.27 and the highest indicator of creative thinking that is achieved is thinking fluently.

\section{REFERENCES}

[1] Sari, I. M., Sumiati, E., \& Siahaan, P. (2013). Analisis Kemampuan Berpikir Kreatif Siswa SMP dalam Pembelajaran Pendidikan Teknologi Dasar (PTD). Jurnal Pengajaran MIPA. 18(1), 60-68.

[2] Jamaluddin. (2018). Raport Merah SMA/SMK Aceh. Aceh: Serambi.

[3] Munandar, U. (2012). Mengembangkan Kreativitas Anak Berbakat. Jakarta: Rineka Cipta.

[4] Tridjata, S. (2002). Mainan Pendidikan sebagai Media Ekspresi Kemampuan Kreatif Anak. ITB Central Library.

[5] Baucus, M. S., Norton, W. I., Baucus, D. A., \& Human, S. E. (2008). Fostering Creativity and Innovation Without Encouraging Unethical Behavior. Journal of Business Ethics, 81(1), 97-115.

[6] Craft, A. (1999). Creative development in the early years: some implications of policy for practice. The Curriculum Journal, 10(1), 135150

[7] Karim, A. (2014). Mengembangkan Berpikir Kreatif melalui Membaca dengan Model Mind Map. Perpustakaan Libraria, 2(1), 29-45.

[8] Retnawati, H. (2016). Analisis Kuantitatif Instrumen Penelitian. Yogyakarta: Parama Publishing.

[9] Marwiyah, S., Kamid, \& Risnita. (2015). Pengembangan Instrumen Penilaian Keterampilan Berpikir Kreatif pada Mata Pelajaran IPA Terpadu Materi Atom, Ion, dan Molekul SMP Islam Al Falah. Jurnal Edu-Sains, 4(1), 26-31

[10] Samosir, T. (2013). Pengembangan Asesmen Asam-Basa Berbasis Keterampilan Proses Sains. Tesis. Universitas Lampung: Bandarlampung.

[11] Baehaki, F. (2014). Pengembangan Instrumen Assessment Kelarutan dan Hasil Kali Kelarutan Berbasis Keterampilan Proses Sains. Tesis Universitas Lampung. Bandarlampung.

[12] Agustin, D. (2015). Pengembangan Instrumen Asesmen Pengetahuan Pada Materi Teori Atom Bohr dan Mekanika Kuantum. Tesis. Universitas Lampung: Bandarlampung.

[13] Alrubaie, F. \& Daniel, E. (2014). Developing a Creative Thinking Test Iraqi Physics Students. International Journal of Mathematics and Physical Sciences Research. 2(1), 80-84

[14] Kohl, P., Kuo, V., Kowalski, S., \& Kowalski, F. (2014). Promoting And Assessing Creativity And Innovation In Physics Undergraduates. International Journal of Mathematics and Physical Sciences Research. 3(1), 4-8.
[15] Hong, E., \& Milgram, R.M. 2010. Creative Thinking Ability: Domain Generality and Specificity. Creativity Research Journal, XXII(3): 272287

[16] Setyawan, S., Koes, W. \& Wartono. (2017). Kreativitas Siswa SMA Negeri 1 Dompu pada Materi Impuls dan Momentum. Pros. Seminar Pend. IPA Pascasarjana UM. Vol. 2. ISBN: 978-602-9286-22-9

[17] Klenowski, V. (2009) Assesment for Learning revisited: an Asia Pacific perspective Assesment in Education: Principles, Policy, Practice 163 pp 263-268 